\title{
Effective ways for the Classroom \\ Management
}

Mohammed Mizel Tahir

MA. ELT Methodology

\begin{abstract}
:
This study was conducted in order to determine the effective techniques of classroom management that can be used to minimize classroom misbehavior and maximize effective learning. Classroom management is probably the most difficult part of teaching .High school teachers in Iraq, like in all countries, face instances of misbehavior in the form of off-task behavior or more serious disruptions. When a teacher is forced to deal with constant disruptions or a teacher cannot control his or her classroom then learning is not taking place. Thus, the objective of this study is to determine what methods of classroom management are available for teachers. This study used different methods to gather information on the best ways of classroom management. There have been many studies that serve to support universal classroom methods of classroom management techniques.
\end{abstract}

Throughout my humble experience as teacher in college of police I found many Iraqi universities professors and high school teachers are still sticking with traditional (outdated) ways and techniques of teaching English regardless of their learner's needs and motivations. Thus the teachers have to think with the central question being "what do these students need and how can I meet those needs."

The significance of this study is that Iraqi and Arab teachers (who use English language as a second language as a means of communication) who are having problems coping with misbehavior in their classroom can use the techniques recommended by this study in order to improve their classroom management.

This study found that there are varieties of techniques taken from the classroom management theories that aid in improving classroom management. 


\section{Introduction}

This study aims at developing teachers performance by putting a new strategies and guidance plane plus technique for effective ways of integral learning (classroom management).Such a way of learning will create successful learning environment which increase and enforce learners motivations and achievement by removing the hinders/barriers between teacher and students and thus we can achieve meaningful learning class.

\section{Classroom Management Plan}

Classroom Management encompasses most aspects of teaching. It refers not only to the ways in which a teacher responds to the negative behaviors in her classroom, but the ways in which she plans for, designs, implements and manages both the tangible and intangible features of a positive learning environment. A classroom management plan is consistent with a teacher's style and personality, and addresses the physical features of the classroom, the rules, the procedures, assessment and the role of parents in supporting that plan. Since a classroom management plan is a direct product of one's own philosophies about teaching, and one's decisions will likely come under question, as will the policies behind them, teachers should be prepared with a well-thought out plan for managing their classrooms.

\section{Philosophical point of view}

One of the main reasons for teachers entering the teaching profession is that they would like to create positive learning experiences for all students. They would prefer to be the kind of teacher with whom students feel comfortable sharing their problems as well as their joys. Teachers want to show otherwise alienated students that knowledge is for everyone and that if they can just find a way to relate to it they will become lifelong learners. Teachers want to be seen as a trusted adult and friendly mentor. If it's true that teachers are gatekeepers to knowledge and therefore opportunity, then they know that the way that they teach and the 
way they manage their class, will have a large impact on whether the students are even interested in the keys to the gate. Teacher classroom management plan is designed to create a safe, supportive, student centered learning environment, where students can feel comfortable taking personal and educational risks and one in which students are always treated with dignity.

Teachers take a lot of their philosophy from the idea of what is considered "professional" behavior, both in the sense of behavior appropriate for the workplace and also in the sense that pride in one's work, leads to behavior consistent with that pride. Expectations for professional behavior apply to the teacher as well as the students. Far be it from them to support the churning out of well indoctrinated corporate drones or to create artificially formal atmosphere. Rather they seek to nurture the kind of courtesy, honesty and diplomacy essential to civilized co-existence. It's the idea that good manners are practiced not so that everyone is intimidated into risk-less silence or reduced to saccharine phoniness, but that we can feel secure that our behavior sets others at ease. Many people, adults included, need explicit training in professional behavior. They need to learn what professional behavior is and how one becomes skillful at it the same way one learns a foreign language, practice! But students also need the second ingredient, pride in their work. And to have pride in their work, they must feel that work is valued, both by themselves and by others. A teacher needs to learn about the values and cultures of her student's personal communities. He/She must learn to understand what motivates her individual students. This seems like common sense, common decency and consideration.

\section{Classroom Arrangement}

The physical environment of the classroom communicates a lot about how much learning and people are valued. Often the teacher or school has very little control over the major aspects of the physical environment. For example, I am teaching this year in a classroom in college of police that used to be the main office of the high school. There are conference room tables and chairs for the students to sit in. At first we thought the students might like this arrangement better than the traditional student desks because they were being treated like grownups and in some ways had more room than with the old desks. And they did like it. However, it didn't 
take us long to discover that it was impossible to arrange the tables in an equitable relationship to each other or the important spaces of the room. We couldn't move easily between the tables to consult quietly with students on the inside. It was cumbersome to move into groups for group work. We have since ordered traditional desks and I will be the first to unload the truck and move the old furniture out.

Our plan will arrange for the teacher to have a space for teacher only stuff, but it will not necessarily be at the head of the classroom and we won't be positioned there for most of the class time. As you can see by my illustration, we believe they can observe the board, but they can also see each other so that class discussions can be facilitated quickly and easily. Other arrangements, such as foursomes and small and large circles should be easy to get into as well so that both teachers and students are not reluctant to engage in them.

The art and other materials (maps) on the walls should reflect the communities and cultures of the students in the class. Student work should dominate and should rotate throughout the year. Books, dictionaries, computers and other materials and resources should be stored in spaces easily accessible by students.

Many other physical features of the classroom will depend on the real physical features and material resources of the individual school. But regardless of the less controllable factors, the classroom should communicate that students are at its center.

\section{Classroom Rules}

In order to promote a student-centered classroom, the students must be involved in setting the classroom, rules or norms or expectations. Student created expectations make them that much more powerful because they own them. However, we reserve the right to rules, no hats or sunglasses; no eating and regular attendance is required to pass the class. Many students today and from our generation simply do not know or understand this tradition and need to be educated about it. Similarly, we believe that eating in the classroom does not communicate the kind of seriousness about the work of the classroom that such work deserves. One does not bring their lunch to a business meeting unless it is of course a lunch meeting. 
As far as attendance policies, we glad that they are usually set by the school. It's important that schools have a consistent policy that applies to all students, and that teachers are supported in their attendance policies. If we look to a professional model, punctuality in business is essential both for success and efficient respectful process. In school, College and group work relies on the reliability of the participants.

Other than those rules, the students will set the rest of the expectations or norms for the class. We have seen this done many times and if it is presented and facilitated carefully, the students usually come up with reasonable norms that respect their peers and with which everyone can live. This is an exercise that should be done in the first few days of school, if not on the first, and it should be presented in terms of "What do you need to feel safe in a classroom?" and "What do classrooms need in terms of behavior to be productive?"

\section{Classroom Climate}

\section{The ideal classroom should give the following climate:}

- $\quad$ Friendly

- Classroom will be decorated with a theme for the lessons taught throughout the year

- Plants

- $\quad$ Animals (hamster, fish, birds)

- $\quad$ Students work will be displayed; often our lesson will contain themes

- There will often be classical music in the background, as it has been found to stimulate learning

\section{Classroom Procedures}

Everyday starts with some ritual that uses either reading or writing. We've worked in classes that began everyday at 9:00 morning and others that began with 10-15 minutes of independent reading. We can see a plan that uses both, alternatively. These 
rituals are important for several reasons. First, they give the teacher time to do small tasks like take attendance and final prep minutes. They quiet the class and focus their thinking. They practice some academic skill and in the case of journal writes, give the opportunity for communication between the teacher and student.

Lesson plans should flow along an organizing principle that relates to an essential question to which all students can relate. Lesson plans should review what has gone before and preview what is to come. They should employ all of Gardner's multiple intelligences and they should be both accessible and challenging. Activities should vary everyday and take into account the other activities and events on the school calendar.

\section{Setting Rules}

Effective management requires proactive teachers to define their expectations for their students. Therefore the teachers should communicate her/his social and academic expectations at the beginning of the school year. Many teachers find it necessary to establish a list of rules that classifies their expectations from student behaviors. There are some properties of a list of ruler

Establish the list during the first few class meeting.

Keep the list short.

Include only these rules that you consider necessary to be prepared to explain why each rule is needed.

State each rule simply.

Involve students in setting rules.

Focus on student behavior need to achieve lesson goals.

State consequences for breaking rules.

State rewards for the follow in rules.

Although this list is teacher's responsibility but the students should be involved, too. Such involvements can motivate the students to obey and accept the rules. But most of the teachers don't involve the students because they think they give the control of the authority to students. On the other hand by involving the students on the list, the goal of self- discipline can be established.

\section{Wittiness}

The teacher whose students are at high level of achievement, do not wait for the trouble to disturb and then respond to the undesirable behavior. Also there teachers are aware of events that can occur during a classroom day. A teacher's ability to be aware of events occurring simultaneously in the classroom called 
wittiness. During times when students completed their seatwork assignments, these teachers monitor the students' behaviors. If the students demonstrate unexpected behaviors, these teachers calmly intervened and stopped the unwanted behavior by getting students back on task.

\section{Overlapping}

The teacher's ability to manage more than one classroom activity at a time is called overlapping. Effective teachers can manage this. While the teacher is working with one group, he/she has the ability to attend to other students. Also these teachers use management tactics while conducting the activities. Teacher can effectively overlap by pausing momentarily to comment on each student's work and by periodically looking up and controlling the class. Another way to overlap is to casually direct a question or comment to a student who appears to be disengaged in the lesson, especially who is disturbing the class.

\section{Lesson Momentum}

Kounin(1970) found that the best classroom managers were careful to keep the lesson moving at a brisk pace. Inappropriate student behaviors increase when the lesson becomes boring. Effective teachers set a time limit for the task so that they motivate students.

\section{TECHNICAL TEACHING SKILLS}

Most of the inappropriate behaviors result from ineffective instructions so that teachers use verbal and nonverbal technical skills as a part of effective instruction.

\section{A)Verbal Skills:}

\section{1)Set Induction:}

Students often disturb their classes because they do not understand the lesson. The beginning of each lesson is important because this time is the foundation for understanding so that the rest of the lesson is established. Consequently effective proactive teachers get the attention of students before starting the lesson.

Technical teachers use to get all the students' attention are collectively called set induction (Henson,1996). This skill is several ways. For example, teacher can start the lesson by telling interesting stories about the lesson. Other teachers start the lesson setting the instructions about the lesson to get the attention of 
students or the teachers speak softly that the students listen carefully to hear.

\section{2)Voice Conrtol:}

Teachers can communicate verbally, if they are heard so that sufficient vocal volume is crucial. Unfortunately many teachers find it difficult to overcome the voice control at elementary and secondary classrooms. On the other hand, most of the

Teachers can overcome the voice control problem by taking a few simple precautions. Beginning teachers and experienced teachers do the same mistakes because beginning teachers look at he students from the front of the class and speak loudly enough for these students hear and experienced teachers ask questions to the students which are in the front so that they speak softly that the students in the back can't hear. In order to correct this faulty the teachers must comment their questions to the students in the back of the classroom or farthest from you. With another method, by arranging the class in semicircles every student can hear the teacher sufficiently.

3)Varying Instructional Methods:

Young students typically respond positively to stimulation and variety in the classroom curriculum (Henson\& Eller,1999;413). The variety of activities in the lesson increase student participation, attention and motivation. When planning to avoid to avoid classroom management problems, the teacher use the same method. They prepare a variety of activities and alternatives into their lesson to prevent student behavior problems and to motivate the students. The activities are varies that such as lecture, games, discussions, groupwork studies,. Also a variety of media can help such as TV, computer, radios, cd player,...etc.

\section{B)Nonverbal Skills:}

\section{1)Time on Task:}

Students who are kept busy doing a task, don't cause inappropriate behaviors or disturbance. The difference in amount of time spent on task vary from school to school. According to Henson\& Eller(1999;414) a distinction should be made between assigned time and engaged time: for example the students could be assigned the last 15 minutes of the period to work problems only an average of 2 minutes; the time on task should be the teacher's focus. Effective teachers first plan assigned time and the engaged time. 


\section{2)Eye Contact:}

While teachers are speaking they focus their attention on their notes, textbooks, or they may look on the floor, ceiling but not to students. But they don't know that direct eye contact tells the students that the teacher knows what they are doing.

In order to improve eye contact the teacher may use few notes and plan, a few very general state or use overhead projector so that he/she will not lose the control of the students. While using blackboard the teacher turn his/her back so that loses the control.

\section{SOLVING IMMEDIATE PROBLEMS}

An effective proactive teacher spends much time on preventing problems rather than solving problems. But there are times when all teachers face troubles that occur during a lesson.

\section{A)Using Silence:}

Most teachers talk too much because of the responsibility for maintaining and directing class interaction. Also they think that they are authority in the class so the person who talks much should be them. But silence can be effective to discipline students. Unfortunately the teacher find this very difficult. Think of a lesson; you are talking too much and the attention is decreased and students start to talk with each other. When the teacher suddenly starts to speak softly and with a low level of voice, the students' attention will be raised to the teacher and the lesson because they will try to hear what the teacher is talking about.

\section{B)Proximity Control:}

While the teacher is talking, if he/she moves closer to students, this will have different meaning. According to Elleson\& Henson(1999;417) first it means " I am standing close to you", secondly "I don't like your company", an the last "We have something in common". With this approach you control the students easier than other approach because the distance with you and the students are very nearby. On the other hand in a lesson several management skills should be used.

\section{C)Teacher-Student Conferences:}

Some students who don't change their inappropriate behaviors in to appropriate, have big problems. In order to solve these problems, a conference is a good way. The successes of the conference depend on the manner in which it is conducted. Because the teacher's manner shouldn't be to attact to student rather the 
teacher should be positive, calm, kind in order to communicate with the students, to help the student make behavioral progress.

\section{PUNISHMENT AND DISCIPLINE}

Another strategy used to solve discipline problems is punishment. Punishment is defined as the presentation of an aversive stimulus that weakens the behavior it follows (Skinner;1953). Through the years this approach was very popular an all over the world but today it is forbidden. Punishment and threat of punishment play a destroying role between the student, school and the teacher because this method prevents the students to be active and to study. Consequently the student starts to dislike to school. Later it is seen that punishment is just a temporary solution, it doesn't bring an end to disturbance student behaviors.

According to Henson\&Eller(1999;419-20) following are several qualities that deter many teachers from using corporal punishment:

Corporal punishment attacts the person, not the behavior

Corporal punishment addresses only undesirable behavior; it doesn't address desirable alternatives

Corporal punishment does not attempt to seek out the underlying cause(s) of inappropriate behavior

Corporal punishment can lower students' self-esteem, thus promoting further misbehavior

Those teachers who use corporal punishment the most are apt to be the ones who have the least understanding of its ramifications

Corporal punishment can and at times does result in permanent physical damage

Corporal punishment carries the subtle message that the best way to deal with life's problems is by using force

Corporal punishment is often used as a substitute for good planning

Corporal punishment establishes a barrier between teachers and students

Corporal punishment lowers other students' respect for the teacher and causes students to be fearful of teachers and school

Perhaps most important, there are alternatives to corporal punishment that are more effective in reducing inappropriate behavior and don't have the negative side effect.

\section{A)Time Out:}

A way alternative to corporal punishment for reducing inappropriate behavior is called time out. With this procedure the misbehaving student is removed for a short time from the situation. 
The time out place should be dull and simple. There shouldn't be anything reinforcing the disturbing behavior so that the student will be cut from the classroom activity. Bu it mustn't be forgotten that the time out shouldn't be used to frighten the student. For the time out to be effective, a student shouldn't stay isolated for a long time. Often 5 or 10 minutes is enough for the appropriate behavior. After that the teacher establishes the calm atmosphere in the lesson.

\section{PEER RELATIONS}

Peers play an important role in a student's schooling. Peers serve as reinforces by giving or withdrawing attention and approval; they also serve as model and basis for social comparisons (James\& Egel;1986). Educators emphasize the relationship between teachers and students because the relation socializes attitudes, values and abilities of the students. Peer relations contribute the students' perception of their successes. On the other hand the poor peer relations during childhood can result as isolated from society and psychological problems occurring during childhood, adolescence and adulthood. Positive peer relationships can reduce social isolation and improve social academic abilities.

when one student 's idea, attitudes, information or conclusions are incompatible or disagree with those of another student (Henson\&Eller; 1999;423).”.

Teachers should form a cooperative climate for such controversies by requiring students to give accurate and complete information during disagreements and requiring each to listen. On the other hand the teacher should define controversies as problems that can be solved so that when they are discussing they don't attach to each other.

\section{MOTIVATION}

\section{From Your Point of View, What Motivates Students?}

We believe that the most important tool to motivate students is to keep them active in lessons they enjoy or find interesting. The fastest way to loose the interest of a student and their motivation is boredom. Kids are capable of absorbing so much yet they need to be kept active and using their energy. Also kids need to know that 
they are not only learning what must be learned by also that there will be a reward at the end of the lesson whether it is materialistic or not.

\section{How Does Your Assessment Promote Your Management Goals?}

It will be important to take notes of each lesson or activity of the day for each student and how they managed that lesson or activity. This will be done through observations and actual work completed. At the end of the day we also reflect on that day's activities and how the students reacted, how they affected our original lesson plan and how we changed my original plan throughout the day. This will be completed through what we call our teaching journal, because anyone can improve their own ways, in this situation our teaching methods.

These techniques will help us modify our lessons and class activities to improve our management goals.

\section{How Do You Allow For Variable Styles, Cultures and Circumstances in Meeting The Diverse Needs of Your Students?}

Just by the fact that we live in the Arab nation, which is so rich in cultures there is going to be so much fun to incorporate in to lessons. All students can share their cultures by doing special project about their lifestyles at home, family history, foods, clothing, religion, etc. students love to share and tell. We can have a culture share day.

Also, just by all students being different they have so much to share about themselves, so we can have a day about us, where students can tell why they dress a certain way, why they wear their hair a certain way, what sports they like to play and so on. Students will find this enjoyable sharing.

Lastly, we can have the students complete a project of how they can teach a lesson. It must incorporate a subject such as Math, English, Writing, Science, or History. But they can teach it anyway they want and using methods that they make up, such as teaching a math lesson. All lessons will be shared with students and parents on a family day.

- Gide to Classroom Control for college and professional School Teachers` Role

1- Focusing: 
Be sure you have the attention of everyone in your classroom before you start your lesson.

DON"T attempt to teach over the chatter of students who are not paying attention.

\section{2- Outlining of the Objectives:}

Outline what you and your students will be doing in the class (written with time limits for each task)

\section{3- Environmental Control:}

A classroom can be a warm cheerful place. Students enjoy an environment that changes periodically. Attractive colors invite enthusiasm to your subjects. For students, (the splash and the color) is a siren that pulls them off task.

\section{4- Solving Problems:}

A teacher anticipates problems before they occur. But if you face a problem, be quiet and calm. Don't interrupt the class by yelling or become nervous.

\section{5- $\quad$ Positive Discipline:}

Use classroom rules that describe the behaviors you want instead of listing things that students can't do .

6- Teachers must constantly be conscious of the necessity of catching them being good. This helps maintain group focus during lessons. Most teacher comments are neutral or negative; only about $5 \%$ is praise directed at the students' academic/social performance. For every negative or neutral comment made, a teacher should attempt at least two positive comments.

7- Effective teachers manage their classes so that students spend their time (and the teacher her's) more productively (engaged time).

8- Preventing misbehavior. A classroom in which the teacher has complete lesson plans, structured organization (e.g., activities start/end [transitions] on schedule with minimum disruptions, and routine procedures are handled quickly and/or simultaneous with other activities) helps to increase engaged time while decreasing the probability of off-task behaviors. 
9- Establishing an individualized behavior modification program.

10- Establish internal validity (reversal or multiple baseline). Fade program.

11- Keeping the students focused and wanting to learn

The most important thing that a teacher must have is being able to explain the content CLEARLY.

12- Responding forcefully and fairly to challenges to your authority Remember that adult learners are much smarter than they appear. You handle challenges by making the challenger appear silly in front of his or her peers.

13- Teachers are also responsible for creating a learning environment, not just an orderly classroom.

14- Teachers should be aware of how their background influences what they see as a behavior problem and the differences in the cultures of their students.

15- It would seem that the best strategies to manage a classroom are positive reinforcement and explanations, such as "discussing correct or desired behavior" with the student of the whole class.

16- Establishing a class community, the class as a whole can be utilized to help make decisions on solutions to behavioral problems. Just as a class that makes it's own rules will follow those rules better than ones that were strictly teacher-imposed, so will a class that creates it's own solutions to their problems respond better to those solutions. This strategy works best with older elementary students through secondary students.

17- Teachers have a powerful influence on the lives of students. The way we as teachers manage our classrooms is very important to how our students learn and grow as people. We need to foster a safe learning environment where children feel comfortable taking chances, and yet do not impede on another student's learning.

18- Teacher knowledge of the content. Students will judge this (rightly) by your ability to answer their questions.

\section{Techniques that can help you achieve effective group management and control in the classroom:}


- How to gain your students' respect:

1- Be consistent in what you say and do.

2- Don't ask them to do anything you wouldn't do.

3- Use reasonable comments on the behavior not the student.

4- $\quad$ Give encouragement freely; avoid extra praise.

5- $\quad$ Anticipate problems before they arise.

6- Be flexible.

7- $\quad$ Help students feel capable.

8- Use monitoring

9. Multi-tasking

10. Use signals, body language, and movement

11. Communicate with students

12. Avoid suspensions

\section{Techniques from Confronting-Contracting Theory}

1. Support self discipline

2. Encourage peer-tutoring

3. Give positive reinforcement

4. Avoid tangible rewards

\section{Techniques from Rules and Consequences Theory:}

1 Follow through with consequences

2. Don't punish the group for the actions of one

3. Explain reasons for giving any consequences

\section{Techniques not exclusive to one theory:}

1. Control the Leaning Environment

2. Control classroom seating

3. Have well-planned and interesting lessons

4. Give appropriate lessons 
5. Teach to your strengths

6. Set clear rules from the first day of class

\section{Give proper guidance Classroom Management}

\section{CONCLUSION}

We have tried to define and explain classroom management but we have learnt too many techniques. First-year teachers think that classroom management is the biggest problem because getting the attention of the students and motivate them is very difficult. We were also thinking what we are going to do when we start teaching but when we have read many books on that subject (classroom management) we find that it has some tactics to be used. Silence is the easiest management skill to use, yet it is the least used. If a first-year teacher uses this and the other explained, he/she will act as an effective teacher.

The researcher has found it is important to put variety lists of techniques that agreed and overwhelmed all over the world among many educationalists and scholars. If you followed those strategies and techniques you will be a successful teacher. 


\section{Resources:}

-Alberto,P.A., Troutman,A.C.,(1986),Applied Behavior Analysis For Teachers ,ed. K.T. Henson\&B.F.Elle r(1999;404), Educational Psychology For Effective Teaching, Wadsworth Publishing Company,USA -Allwright,D,\&Bailey,K.M.,(1991),Focus On The Language Classroom, Cambridge University Press Company, USA -Churchward, B. Techniques for better classroom discipline. p. 1-5. -Curwin and Mendler (2001) Discipline with Dignity. ASCD -Emmer, E.T., Evertson, C.M. and Worsham, M.E. (2000) Classroom Management for Secondary Teachers. Needham Heights, MA, Allyn \& Bacon.

-Henson,K.T.,(1996),Methods And Strategies For Teaching In Secondary And Middle Schools(3rd Edition),ed.K.T.Henson\&B.F.Eller(1999;412), Educational Psychology For Effective Teaching,Wadsworth Publishing Company, USA -Henson,K.T.,Eller,B.F., (1999), Educational Psychology For Effective Teaching, Wadsworth Publishing Company, USA

-Homme,L.,Csanyi,A.P.,Ganzales,M.A.,Rechs,J.R.(1970), How To Use Contingency In The Classroom ,ed.

-James,F.A.,Egel,A.L.,(1986),A direct prompting strategy for increasing reciprocal interactions between handicapped and nonhandicapped sibling:Jurnal of Applied Analysis, 19,pp.173-186 ed.

-Johns, K.M., \& Espinoza, C. (1996). Management strategies for culturally diverse classrooms. Fastback, Phi Delta Kappa Educational Foundation, p. 7-44. -Jones,V\&Jones,L.,(1995),Comprehensive Classroom Management, ed.

-K.T.Henson\& B.F.Eller(1999), Educational Psychology For Effective Teaching, Wadsworth Publishing Company,USA

-Kounin,J.,(1970),Discipline and Group Management in Classrooms, ed. -Nathan,M.,(1996), The Head teacher's Survival Guide, Kargen Page, London -Nelsen, J. No more logical consequences - at least hardly ever! focus on solutions. p.1-2.

-Prosise, R. (1996). Beyond rules and consequences for classroom management. Fastback, Phi Delta Kappa Educational Foundation, p.7-37.

-Skinner,B.F.,(1953), Science and Human Behavior, ed. K.T.Henson\& B.F.Eller (1999;418), Educational Phychology For Effective Teaching Wadsworth Publishing Company,USA

-Smith,R.,(1988), Child Education, ed. Roger Smith(1995;90), Successful School Teaching, Cassell, Great Britanian Smith ,R.,(1995), Successful School Management, Cassell, London

-Sulzer-Azaroff,B.\&Mayer ,R.G.,(1991), Behavior Analysis For Lasting Change, ed. -Tharp,R.G.\&Gallimare,R., (1988), Rousing Minds to Life, Cambridge University Press, USA

-Tulley, M. \& Chiu, L.H. (1995). Student teachers and classroom discipline. Journal of Educational Research, $\underline{88}$ (3), p.164-171. 


\section{طرق فعالة لإدارة الفصول الاراسية \\ محمد مزعل طاهر}

وقد أجريت هذه الدراسة من أجل تحديد الأساليب الفعالة لإدارة الصف والتي يمكن استخدامها للحد من سوء

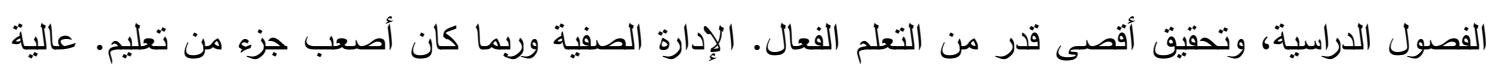
معلمي المدارس في العراق، كما هو الحال في جميع البلدان، وحالات مواجهة سوء تصرف في شكل فن من أثنكال

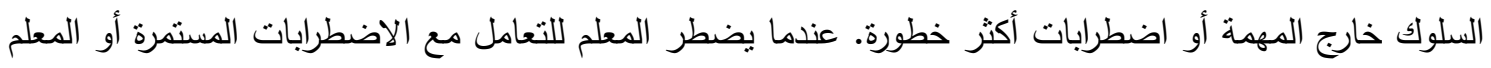
لا يمكن التحكم به أو الفصول الدراسية لها ثم تعلم لم يحدث. وبالتالي، فإن الهدف من هذه الدراسة هو تحديد ما ها

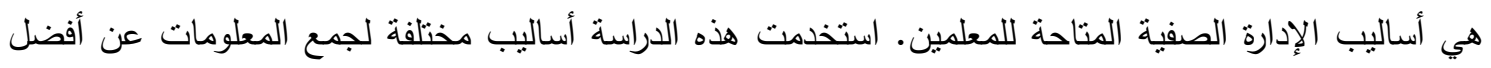
السبل لإدارة الصف. كانت هناك العديد من الدراسات التي تعمل على دعم أساليب الفصول الدراسية العالمية لتقنيات إدارة الصف. لإدة الصف.

طوال تجربتي المتواضعة مدرسا في كلية الثرطة وجدت العديد من الجامعات العراقية أساتذة ومعلمي

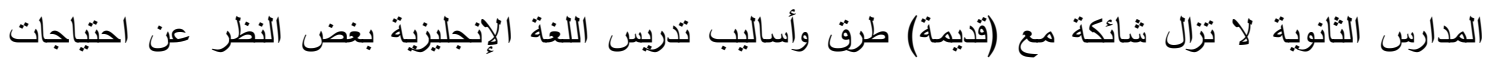
المتعلم الخاصة بهم والدوافع التقليدية. وبالتالي فإن المعلمين على التفكير مع السؤال المركزي يجري "ماذا يحتاج هؤلاء الطلاب وكيف يمكنني تلبية تلك الاحتياجات."

وتكمن أهمية هذه الدراسة هي أن المعلمين العراقيين والعرب (الذين يستخدمون اللغة الإنجليزية كلغة ثانية كوسيلة للاتصال) الذين يواجهون مشكلات في التكيف مع سوء السلوك في صفوفهم يمكن أن نستخدم التقنيات الموصى بها في هذه الدراسة من أجل تحسين صفوفهم إدارة. وجدت هذه الدراسة أن هناك أنواع مختلفة من التقنيات التي اتخذت من نظريات الإدارة الصفية التي تساعد في تحسين إدارة الصف. 